\title{
Local Perceptions of Corporate Social Responsibility for Arctic Petroleum in the Barents Region
}

\author{
Ilan Kelman \\ Institute for Risk $\mathcal{E}$ Disaster Reduction and Institute for Global Health, University College \\ London, London, UK \\ Norwegian Institute of International Affairs, Oslo, Norway \\ Julia S.P. Loe, \\ Fridtjof Nansen Institute, Oslo, Norway \\ Elana Wilson Rowe, \\ Norwegian Institute of International Affairs, Oslo, Norway \\ Emma Wilson, \\ ECW Energy Ltd, London, UK \\ Nina Poussenkova, \\ IMEMO RAS, Moscow, Russia \\ Elena Nikitina, \\ IMEMO RAS, Moscow, Russia \\ Daniel Buikema Fjærtoft \\ Sigra Group, Oslo, Norway
}

\begin{abstract}
Corporate social responsibility (CSR) is promoted and critiqued by many players involved in or opposed to petroleum exploration and extraction, although a common understanding of CSR's theoretical and practical meanings rarely exists. This paper uses Arctic petroleum in the Barents region (Norway and Russia) to investigate local perceptions of CSR. We conducted open-ended, semi-structured interviews in four locations: Hammerfest, Murmansk, Komi Republic, and Nenets Autonomous Okrug (NAO). Interviewees included the local population, regional and local authorities, non-governmental organisations (NGOs), and petroleum company representatives. The field research suggests that those who gain directly from the petroleum industry and do not directly experience negative impacts were more inclined to be positive about the industry, although overall, general support for petroleum activity was high. In some cases, positive economic benefits resulted in greater tolerance of environmental risk. Sometimes, the industry and government were criticised by locals for failing to support a more equitable distribution of broader economic benefits. Rather than splitting along fer-profit/NGO or indigenous/non-indigenous lines, our analysis suggests that
\end{abstract}

^Correspondence to: Ilan Kelman, University College London, IRDR, Wilkins Building - South Wing, UCL, Gower Street, London, WC1E 6BT, UK; Norwegian Institute of International Affairs, C. J. Hambros plass 2, NO-0164 Oslo, Norway. Email: ilan_kelman@hotmail.com 
those who are closer to the petroleum industry or its benefits, termed 'insiders', tend to be more positive than 'outsiders'. This study is perhaps the first of its kind in its focus on local perceptions of CSR for Arctic petroleum across the Barents region. The findings of this study not only match with that of the previous literature on Arctic petroleum but also provide further practical and theoretical insights by indicating subtleties and nuances within the localities examined.

Keywords: gas; Hammerfest; Komi Republic; Murmansk; Nenets Autonomous Okrug (NAO); Norway; oil; Russia

Responsible Editor: Tore Henriksen, University of Tromsø, Norway.

Received: March 2016; Accepted: October 2016; Published: November 2016

\section{Introduction}

Corporate social responsibility (CSR) is frequently of interest to those involved in or opposed to petroleum exploration and extraction, although a variety of CSR understandings and approaches exist. ${ }^{1}$ Corporations, local community sectors, nongovernmental organisations (NGOs), and academics often have widely different perceptions and views on what the 'CSR' term means and entails, leading to a range of outcomes, from academic debates about semantics to on-site protests over diverging or disappointed expectations.

The petroleum industry is often seen as being a leader in industrial CSR policy and practice; however, it is also frequently criticised for a lack of openness, in particular, regarding mistakes; for overt 'greenwashing'; and for failing to account for wider consequences of petroleum development and use such as climate change and resource depletion. ${ }^{2}$ Studies have also highlighted challenges faced by the petroleum industry in implementing CSR principles and practices across its workforce and throughout its supply chains. ${ }^{3}$ As in many policy fields, moving from policy statements to implementation and practice is where much CSR-related complexity lies.

One area of importance for petroleum-related CSR is the Arctic. ${ }^{4}$ Both Russia and Norway have recently been increasing their Arctic petroleum activity, ${ }^{5}$ primarily offshore and focusing on the Barents region, which straddles the two countries' border, the maritime boundary of which was delimited in 2010 after decades of disagreement. ${ }^{6}$ Expectations of declining oil reserves and increasing prices have put the long-term potential of Arctic petroleum in focus, notwithstanding safety and environmental concerns, technological challenges, and high production costs. Despite the recent oil price drop and shale gas expansion in the USA, Arctic oil and gas remain important. In Russia, Arctic onshore petroleum fields continue to be significant contributors to overall production. In Norway, the government's and industry's desire to exploit new areas keeps the sector looking northwards, towards the North Sea and the Norwegian Sea. ${ }^{7}$

Changing forecasts over the past decade regarding Arctic petroleum development further highlight the challenges local communities face when they base their longterm socio-economic development plans purely on future petroleum possibilities. ${ }^{8}$ 


\section{Kelman et al.}

Research has analysed perspectives from nomadic and settled communities in the Barents region and neighbouring Western Siberia ${ }^{9}$ and industry-society relations around the Barents and CSR. ${ }^{10}$ Attention to circumpolar Arctic business issues is also growing, for example, through the recently launched Arctic Economic Council and the Arctic Investment Protocol. This work and these initiatives highlight the need for increased in-depth case studies of state/community-business relations in the Arctic and for rigorous cross-location comparisons.

This study contributes to filling this gap by examining and comparing local perceptions of CSR in the Arctic petroleum industry in the Barents region. It is perhaps the first study of its kind in comparing case studies across the Barents region, which is currently the most active in Arctic petroleum exploration and extraction. To fulfil this goal, this paper draws on one location in northern Norway and three in Russia. Two locations have long-term community experiences of petroleum-related CSR (Komi Republic and Nenets Autonomous Okrug (NAO) in Russia), one location has more recent oil and gas development (Hammerfest, Norway), and one location involves full-scale petroleum development that was never realised (Murmansk, Russia, in relation to the Shtokman field). The next section of this paper provides a brief overview of the literature on CSR to place this study in a wider framework. Then, the method and case studies are presented followed by comparative results and discussion. The conclusion summarises the paper's theoretical contribution as well as the way forward for research and policy.

\section{Background to and conceptual framework for CSR}

\subsection{A theoretical overview of CSR}

CSR is understood in different ways by different people in different sectors in different parts of the world. ${ }^{11}$ The 'social responsibility' of business emerged as a concept in the nineteenth-century European literature and practice in the context of the industrial revolution and focused on companies' responsibilities towards their workforces and the local communities. ${ }^{12}$ The concept also evolved in the USA in the 1950 s in debates on the need for businesses to respond to society's evolving moral expectations. ${ }^{13}$ Since then, research and debate regarding CSR have expanded in academia and in business management practice. ${ }^{14}$ Despite the wide-ranging nature of these debates, research on CSR has been criticised for under-representing the perspectives of non-business actors. ${ }^{15}$ This paper sets out to contribute to redressing this gap.

Notwithstanding substantial discourse on CSR, no common understanding has been developed regarding the different theoretical and practical meanings of CSR or between the different contexts where CSR has evolved and been applied. ${ }^{16}$ There is also a growing literature from academics and practitioners encouraging sight beyond CSR as an all-encompassing idiom for company-community relations, leading to intense debates regarding theoretical baselines for and definitions of CSR. One metaanalysis examined three decades' worth of CSR literature, exploring three distinct 
views of CSR. ${ }^{17}$ Another meta-analysis mapped CSR theories into four groups, but decried the CSR field's lack of consistency by stating that it 'presents not only a landscape of theories but also a proliferation of approaches, which are controversial, complex, and unclear' (p. 51). ${ }^{18}$ A content analysis of 37 definitions of 'CSR' yielded five distinct dimensions contained within the literature, ${ }^{19}$ while an earlier study indicated how CSR work was expanding into new, diverse concepts labelled 'corporate social performance', 'stakeholder theory', and 'business ethics theory'. ${ }^{20}$

Despite many negative comments in the literature, the various views do not immediately suggest that work on CSR is directionless or inconsistent. Core elements of a CSR agenda can be recognised across diverse CSR studies and initiatives. Examples of these core elements are transparency, equity, human rights, labour rights, environmental protection, sustainable development, anti-corruption, and meaningful stakeholder engagement. Yet different CSR studies focus on these elements in different ways and in different combinations. This diversity of understanding and implementation has been both a theoretical strength and a theoretical weakness of CSR concepts and theories.

The strength is that much empirical work highlights the context dependence of CSR implementation and operations on the ground ${ }^{21}$ even attributing specific characteristics to specific geographical locations such as the USA with its CSR exceptionalism. ${ }^{22}$ Having various conceptual models, definitions, and theoretical baselines from which to choose enables CSR to be applied to many different situations, with the theory morphable to apply to the particular needs of a specific case study. The weakness is that CSR has the potential to be defined according to the context; therefore, some might identify CSR in a context, whereas others only find a few core elements. Divergent and potentially contradictory meanings and applications may result, leading to flawed empirical results. For instance, one analysis suggests that the impact of CSR on a company's financial performance is skewed in many empirical studies because the investment in research and development variable is missing. ${ }^{23}$ In another paper, the same authors then apply their findings to develop a theoretical model of an ideal level of investment in CSR for a company, ${ }^{24}$ but use a baseline assumption that implies that context might be the same for all the companies considered.

Empirical studies of case study comparisons of $\mathrm{CSR}^{25}$ indicate that context is not and cannot be the same; therefore, more integrative models that account for different contexts and different governance levels need to be developed. Rather than converging and seeking consistency for theorising and implementing CSR, the literature diverges regarding theories, policies, and practices, even recognising that core CSR activities can lead to harm in communities. ${ }^{26} \mathrm{CSR}$ actions in practice cover the gamut from disclosure of information to the public ${ }^{27}$ to avoiding environmental harm and building meaningful dialogue between stakeholders ${ }^{28}$ to avoiding the creation of economic disparities in communities through salary inflation. ${ }^{29}$ There are theoretical and practical debates regarding whether or not CSR applies to and should be integrated into all business activities ${ }^{30}$ and even whether or not CSR as a concept or process can realistically achieve needed, expected, and desired levels of 


\section{Kelman et al.}

responsible business practice. ${ }^{31}$ Many of the discussions in the literature, however, primarily take a corporate perspective, considering CSR to be the purview of the corporate sector, for corporate entities to define and implement. This paper explores perspectives from other stakeholders, in particular, the communities most affected by petroleum operations. As such, this study has much in common with the Arctic literature that analyses relations between companies and communities, thereby providing detailed understandings of context. ${ }^{32}$

To assist with building shared understandings of CSR 'beyond context', international and national treaties and legislation have been developed to define, discuss, and operationalise CSR. CSR and variations such as 'corporate responsibility' have been defined in international standards, notably in the International Organization for Standardization (ISO) guidance standard on social responsibility (ISO 26000:2010), which defines the social responsibility of an organisation (not only of a business) as:

[the] responsibility of an organization for the impacts of its decisions and activities on society and the environment, through transparent and ethical behaviour that: contributes to sustainable development, including health and the welfare of society; takes into account the expectations of stakeholders; is in compliance with applicable law and consistent with international norms of behaviour; and is integrated throughout the organization and practised in its relationships.

Further important international standards for responsible business practice come from the Organisation for Economic Co-operation and Development (OECD), first published in 1997, with the latest update from 2011 ${ }^{33}$; the UN Global Compact which started in $2000^{34}$; the UN Guiding Principles on Business and Human Rights $^{35}$; and the performance standards of international financial institutions, such as the International Finance Corporation. ${ }^{36}$ These standards highlight the importance of 'meaningful engagement' with communities and other stakeholders. ${ }^{37}$ At the same time, practitioners recognise that standards can only prescribe a proportion of a company's response, while the rest depends on context. ${ }^{38}$

The responsibilities of government in supporting, regulating, and incentivising corporate responsibility and variations ${ }^{39}$ are also essential to consider and are framed in several international conventions, such as the 1998 UNECE Convention on Access to Information; Public Participation in Decision-making and Access to Justice in Environmental Matters (the Aarhus Convention); the 1989 ILO Convention 169 on Indigenous and Tribal Peoples (ILO 169); and the non-legally binding UN Declaration on the Rights of Indigenous Peoples (UNDRIP), adopted by the UN General Assembly in 2007. ILO 169 and UNDRIP establish government responsibilities to grant the right of free, prior, and informed consent (FPIC) to their indigenous populations in relation to resource developments that significantly affect indigenous peoples' lands and livelihoods. ${ }^{40}$ Despite the fact that core principles such as FPIC have been part of international law for more than two decades, they are still being tested empirically, and it has become apparent that the greatest barrier to effective implementation is the lack of a common understanding of terminology and the underlying principles themselves. For example, Greenland, with its Inuit 
government, is taken by some to be the de facto implementation of UNDRIP; yet, others oppose the fact that decisions on mineral exploitation (notably in relation to uranium) have been made primarily by a small number of elected politicians without wider public engagement. ${ }^{41}$ This kind of confusion creates unwelcome uncertainty for businesses operating in these jurisdictions.

The end result from this overview of perspectives and literature on CSR is the baseline that context matters, that views differ, and that one model cannot fit every CSR situation. ${ }^{42}$ Consequently, it is important to explore CSR within the context of the case studies examined here, which is the focus of the next section.

\subsection{CSR in the context of Norway and Russia}

Considering Russia and Norway, national responses to international definitions and treaties differ. Norway ratified the 1989 ILO convention 169 in 1990 and the Aarhus Convention in 2003, whereas Russia has yet to ratify either. Both Norway and Russia have responded positively to the UN Guiding Principles on Business and Human Rights, which apply to both governments and businesses, although Norway has published its National Action Plan ${ }^{43}$ whereas Russia has not.

Assessing a country's relationship to international and national CSR-related statements is only part of understanding the importance and relevance of CSR to petroleum operations within that country. Countries, companies, and communities operate with specific traditions and formal and informal practices in terms of corporate-community-state relations.

Norway has embraced the term 'corporate social responsibility' (bedriftenes samfunnsansvar) and the Norwegian Parliament has developed a white paper on the subject. ${ }^{44}$ Although much of the CSR literature in Norway focuses on the responsibilities of Norwegian companies operating abroad, ${ }^{45}$ Norwegian companies' domestic operations are gaining increasing attention of scholars and analysts. ${ }^{46} \mathrm{In}$ their sustainability reporting, petroleum companies in Norway emphasise their use of local suppliers and the distribution of social benefits ${ }^{47}$ while portraying their CSR contribution to the community in terms of these local employment and business opportunities, alongside support for cultural and social events. ${ }^{48}$

In Russia, the term 'corporate social responsibility' (korporativnaya sotsial'naya otvetstvennost') is still evolving in its modern interpretation, although there are still strong links between some CSR practices today and the interactions between industries and local communities of the Soviet era. ${ }^{49}$ In 2007, the industry-developed 'Social Charter of Russian Business' was approved as an official national document in line with the UN Global Compact. ${ }^{50}$ The document refers, amongst other things, to the involvement of businesses in the development of local societies. Other initiatives include the Code of Entrepreneurial Ethics developed by the Russian Chamber of Commerce and Industry. ${ }^{51}$ A decade ago, virtually no Russian companies were producing sustainability reports, whereas today most large Russian companies have a CSR or sustainability policy. ${ }^{52}$

Furthermore, Russia, unlike Norway, has a federal structure. Consequently, much depends on initiatives taken in each location, with experience varying widely. 


\section{Kelman et al.}

In 2010, for instance, the Republic of Sakha (Yakutia) passed a law 'On the social responsibility of business'. ${ }^{53}$ The Khanty Mansiisk Autonomous Okrug has a welldeveloped framework, which defines, amongst other aspects, how agreements ought to be negotiated between companies and indigenous communities, and it maintains a fund for future generations. ${ }^{54} \mathrm{NAO}$ also has regional-level legislation, which defines relations between companies and communities with experience of negotiating benefitsharing agreements between industry and local communities. ${ }^{55}$ In the Komi Republic, agreements are drawn up between companies and different levels of government, as well as with individual groups, such as indigenous people's organisations. ${ }^{56}$ Many of the studies highlight the challenges faced by the petroleum industry in implementing CSR principles and practices across its workforce and throughout its supply chains. ${ }^{57}$

\section{Method}

Data were collected through open-ended, semi-structured, one-on-one interviews (Table 1), adhering to the ethical guidelines set down by the Norwegian Social Science Data Services and maintaining anonymity and confidentiality of the interviewees as is standard in social science research. ${ }^{58}$ Interviewees were selected based on known contacts in each region, outreach via email and telephone, and then snowball sampling, ensuring that a balance of genders was achieved alongside a diversity of sectors, backgrounds, ages, and cultural groups, including indigenous and non-indigenous. ${ }^{59}$ No children or specific groups often labelled 'vulnerable' were interviewed.

Interviews lasted 30-90 minutes each and were conducted in Norwegian or Russian according to the location. In Norway, interviews were conducted by a native Norwegian speaker. In Russia, some of the interviews were conducted by fluent Russian speakers; in other cases, a fluent Russian speaker was present at all interviews to assist with translation and interpretation. The main vocabulary issue which arose was the translation of 'corporate social responsibility'. In Russia, the term used was korporativnay a sotsialnaya otvetstvennost (KCO), which is a literal and common translation of the term 'CSR'. In Norway, the term used was bedriftenes samfunnsansvar, which is literally translated as 'businesses' society responsibility'. Where interviewees did not know or were uncertain about the term, elements of CSR were described, giving general ideas of how a company might contribute socially and environmentally to a community, along with specific examples.

Table 1. Interviewee data

Case study

Hammerfest

Komi Republic

Murmansk

NAO
Number of interviews 
Interviews took place in the best locations for the interviewees, including in homes, in offices, on the tundra, in community centres, and in cafés. The aim was for each interview to be as much as possible on the terms of the interviewees so that they would feel comfortable.

The basic semi-structured interview guide of a dozen questions, followed by subthemes and possible follow-ups and supplementary questions, was the same for all case studies. Naturally, there were deviations during each interview and in each location, depending on the interviewees' interests and responses, and the direction the interview took. The aim was for each interview to be as free-flowing as possible, leading to flexibility and variation according to each situation, a standard approach for qualitative research involving interviews. ${ }^{60}$ This methodology helps to avoid leading questions while ensuring that what matters to each interviewee emerges from the interview.

To account for both convergence and divergence in interviewee responses, interview transcripts were coded for interpretation using indicators generated from context, namely, an initial read-through of all interview transcripts resulting in coding or keywords drawn from the interview guide or added in response to interview statements. ${ }^{61}$ Interview statements with the same topic code were then aggregated, allowing for consideration of contradictory statements about the same topic and for assessment of the extent to which interviewees' responses were highly individualised opinions or were part of broader inter-subject understandings. For example, more interviewees making similar statements or using similar examples under the 'sustainable development' or 'regional government's role' codes would point to such a broader understanding. These convergences are presented here, noting that detractors and counterexamples were present in each case study.

\section{Case study locations}

All of the case study locations are in the Barents region. The Hammerfest and Murmansk areas both have sea ports. The petroleum development projectsproposed and then stopped in Murmansk, but carried through in Hammerfestare both located offshore in the Barents Sea. NAO's coastline lies along the Barents and Kara Seas, with most of its territory above the Arctic Circle. Komi Republic sits just south of NAO, landlocked but formally part of the Arctic region, due to a Presidential decree ${ }^{62}$ and its membership of the Barents Regional Council.

Hammerfest is a small town in northern Norway with approximately 10,500 inhabitants $^{63}$ of which approximately 1,200 work in the petroleum industry. ${ }^{64}$ Previously, Hammerfest's economy relied heavily on fishing and a little on tourism. Throughout the 1980s and the 1990s, fisheries declined, leading to unemployment and depopulation. The anticipation and reality of petroleum revenues has revitalised Hammerfest, providing jobs, creating a sense of community, and developing optimism for the region. ${ }^{65}$

The natural gas field Snow White (Snøhvit) was the first discovery developed in the Barents Sea, with production starting in 2007. The gas from Snow White is 


\section{Kelman et al.}

transported by seabed pipeline to the Milk Island (Melkøya) plant in Hammerfest where it is processed for transport elsewhere. The processing plant's location is clearly visible from Hammerfest's town centre, enhancing the feeling of living in a petroleum town. The Snow White license group comprises five companies, with the Norwegian oil company Statoil having the largest share at 36.79 per cent. ${ }^{66}$ Oil production started at the nearby Goliath (Goliat) field in 2016, operated by the Italian company ENI. The oil is transported to markets directly from the offshore field without onshore processing facilities. ENI nonetheless has a clear presence in the local community, with a local office and staff of approximately $50 .^{67}$

Murmansk (population 307,257 as of 2010$)^{68}$ is a major urban centre on the Kola Peninsula in northwest Russia and the capital city of Murmansk Province (Murmanskaya Oblast'). The Shtokman gas field, located in the Barents Sea $600 \mathrm{~km}$ north of the shores of the Kola Peninsula, is one of the world's largest natural gas fields. The prospect of developing the Shtokman field was first earnestly pursued in the early 1990s and the mid-1990s.

In 2005, Russia-Norway and Russia-France cooperation agreements were signed to develop this field with Gazprom at the forefront, triggering an avalanche of bids from other international oil companies. ${ }^{69}$ Eventually, Statoil and the French company Total joined a consortium with Gazprom, called the Shtokman Development AG, in 2008. Exploration never took off after the 'shale revolution' in the US drove down gas prices in what had been a target market for liquefied natural gas from the Shtokman field. ${ }^{70}$ The shareholder agreement expired in July 2012, and the costly and challenging nature of the project makes Shtokman a daunting prospect for any company operating in today's gas markets. ${ }^{71}$

The Nenets Autonomous Okrug (NAO) borders the Barents Sea and spreads across an area of $176,810 \mathrm{~km}^{2}$ with approximately 43,000 inhabitants as of $2010 .^{72}$ About half of the population lives in the administrative centre Naryan-Mar. In 2010, the indigenous population of NAO was approximately 11,100, of which 7,500 were Nenets and 3,600 were Komi, many of whom are engaged in reindeer husbandry. Oil production in NAO started in 1984, and today the region contributes about 3 per cent of Russia's overall production. ${ }^{73}$ Oil accounts for more than 90 per cent of NAO's total industrial output, ${ }^{74}$ providing the region with the highest gross regional product per capita in Russia. ${ }^{75}$ Oil and gas production in NAO is dominated by Russian companies, although at the Kharyaga oil field, at the time the research was carried out, the French-owned petroleum company Total E\&P Russia was a project operator and license holder with a 40 per cent stake.

Russia's Komi Republic is located in the northern part of Russia to the west of the Ural Mountains and to the south of NAO. The Komi Republic has a population of a little over 900,000 as of 2010 , spread across a land area of $415,900 \mathrm{~km}^{2} \cdot{ }^{76}$ Of the population, 23 per cent are ethnic Komi, while Russians constitute 65 per cent. Oil was first extracted in the mid-eighteenth century, although industrial development in the early twentieth century was based largely on coal, utilising labour from the network of prison camps or gulags in northern Komi. ${ }^{77}$ Komi's modern oil and gas industry was established in the 1960s and the 1970s. Komi's centre of oil production 
is Usinsk District, which has a population of 40,800. In 1994, Usinsk District experienced one of the world's worst oil spill disasters, when as much as 100,000 tonnes of oil spread out over $186 \mathrm{~km}^{2}$ of tundra. ${ }^{78}$ Since then, the region has experienced multiple oil spills due to the ageing Soviet-era pipeline system and general negligence. In 2013, the spring thaw revealed a major spill that had taken place the previous October, but had not been reported by the oil company responsible. Reports of spills continue into 2015 and 2016.

Lukoil-Komi is the dominant oil and gas company currently operating in the Republic. In 1999, Lukoil bought up the old state enterprise Komineft, establishing the company Lukoil-Komi, and since then has been trying to clean up the legacy of the 1994 spill. In its 2006 Sustainability Report, Lukoil reported that it had eradicated the inherited consequences of 1994, ${ }^{79}$ although much of the ageing pipeline infrastructure still needs to be replaced.

Table 2 summarises key points regarding Arctic CSR and petroleum from each case study.

\section{Results: Perceptions of CSR}

The coding and analysis process discussed in section 3 led to specific themes emerging from the interviews. These themes are presented and discussed in this section, comprising the study's results.

\subsection{Responding to CSR's meaning}

The term 'CSR' proved to be problematic in some instances, with some interviewees being able to engage directly with the term while others could not. In NAO, the Russian term korporativnaya sotsial'naya otvetstvennost was known to most of the interviewees; yet, many of the interviewees rephrased the term when speaking about petroleum companies' responsibilities to contribute to society as part of their industrial activities. Conversely, in Murmansk, the formal translation of the term tended to elicit little response, with the interviewees being reluctant to interpret or refer directly to it. When they were asked to recount and assess the social and environmental engagement of companies more generally, all interviewees responded in detail.

In Komi, the phrase 'CSR' elicited limited response from interviewees. Therefore, the researchers quickly switched to alternative phrases to proceed with discussion on the essence of CSR, rather than spending time explaining a concept that was unfamiliar to most of the interviewees. At the oil company headquarters level in Moscow, there was considerable awareness of CSR, including reporting and strategising, in line with international CSR standards. In Hammerfest, the term 'CSR' and its equivalents in Norwegian were not generally part of the interviewees' vocabulary, but interviewees were easily able to discuss the oil companies' roles and expected roles in the community.

In fact, irrespective of knowing or not knowing the phrase 'CSR', interviewees across all four case studies tended to understand CSR as being standard practices 


\section{Kelman et al.}

Table 2. Key points from each case study with respect to CSR and petroleum

\begin{tabular}{|c|c|}
\hline Region & Key characteristics \\
\hline Hammerfest & $\begin{array}{l}\text { Petroleum development projects are offshore, with some infrastructure in the near-shore area } \\
\text { and near the region's main settlement. } \\
\text { Gas production started in } 2007 \text { from the Snow White field. Oil production started from the } \\
\text { Goliath field in } 2016 \text {. } \\
\text { Mixed population, but mostly Norwegian with some indigenous Sami. } \\
\text { Relatively high levels of local employment. } \\
\text { The area's centre of wealth and power is also the closest settlement to the offshore operations. } \\
\text { Increases in wealth and living standards related to petroleum production. }\end{array}$ \\
\hline Murmansk & $\begin{array}{l}\text { Offshore petroleum development projects proposed, but not realised. } \\
\text { Mixed population, but mostly Russian. Small but regionally significant indigenous Sami } \\
\text { population. } \\
\text { Local employment is not significant (due to the unrealised project and much planned activity } \\
\text { being offshore). } \\
\text { Historically, a highly industrialised region. }\end{array}$ \\
\hline NAO & $\begin{array}{l}\text { Onshore petroleum developments with production since the } 1980 \mathrm{~s} \text {. } \\
\text { Mixed population, significant indigenous populations, and many external workers coming in. } \\
\text { The regional capital Naryan-Mar is located far from the field operations. } \\
\text { Environmental impacts affect rural, mostly indigenous communities. } \\
\text { Historically, not an industrial region before oil production. }\end{array}$ \\
\hline Komi & $\begin{array}{l}\text { Onshore petroleum developments established in the 1960s. } \\
\text { Mixed population, significant indigenous population although officially unrecognised, and } \\
\text { many external workers coming in. } \\
\text { The oil capital of the northern republic, Usinsk, is relatively far from field operations and has } \\
\text { many non-local residents who contribute to decision-making. } \\
\text { Environmental impacts (which are considerable) affect rural, mostly indigenous Komi } \\
\text { communities. } \\
\text { An industrialised region, which has had oil and other industries since the 1960s; so, } \\
\text { industrialisation is deeply established. }\end{array}$ \\
\hline
\end{tabular}

rather than deviations from typical or assumed practices. Such practices include paying taxes, providing jobs for the local community, ensuring environmental protection, and the presence of petroleum making the region a desired location to live and work. Piecing together views from the interviews suggests that CSR-related expectations were principally linked to job opportunities and economic ripple effects, which are considered to be essential for the community's survival and part of what companies inevitably provide, simply by being there - not as special activities in or gifts to the community. In areas that have suffered greatly from environmental damage, notably the rural villages of the northern Komi Republic, the environmental element of CSR was of utmost priority in local discourse, whereas it was given less priority in regions that have not experienced obvious environmental harm.

These broader expectations were expressed in all four regions. One recurring topic in the Russian case studies was 'Soviet CSR', referring to petroleum companies' 
contributions to the interviewees' regions according to practices established during the Soviet period. Some interviewees in Murmansk warmly recited past and present benefits and services provided by the companies to their employees, including support for entertainment, celebrations, travel, pensioner housing, specialised medical care, education, and other social and family services. For example, one government worker explained, 'I grew up in the Soviet Union and remember ... that large companies had as their basic goal not the making of profit, but the support of life for their workers and families ... Of course, you had to fulfil your [production] plan, but this is something different'. In essence, this articulation presents a view of a 'company town', where the people living there are employed and taken care of by the local company. In NAO, interviewees explained that the Western term 'CSR' described something they had always had; the only new aspect was the name 'CSR'. In Komi, local villagers remembered the way in which the dominant industry used to provide support to local agricultural enterprises, which were incorporated into the books of the larger enterprise.

As such, a commonality across the case studies was that, irrespective of whether interviewees knew or used the specific term 'CSR', they had clear expectations regarding the petroleum companies' responsibilities to them and their communities.

\subsection{Responding to CSR's visibility}

Cultural and community projects funded by petroleum companies were prominent in the Murmansk region. Interviewees pointed out that Rosneft has many social projects, such as 'Best Yard in Town', while Total brought opera singers and ballet troupes to perform. Statoil supported many cultural events, partly to bring Norwegian arts and artists to Russia, including exhibitions, music by Grieg, a scholarship program, sporting events, and social excursions.

In NAO, cultural projects and support for local festivals were in some cases funded directly by oil companies, while in other cases funding from oil companies was provided to the regional authorities, who redistributed the money. For example, Statoil funded prizes for traditional, indigenous competitions in a local festival in Naryan-Mar. Total provided free French lessons and donated French literature to local libraries.

Similar projects were seen as being important for Komi, particularly in the rural areas. Usinsk benefits most from a lively oil-based economy due to administrative and service jobs, housing construction, supermarkets, and shopping malls. While oil jobs are available in the rural areas, companies' social investment projects are the more visible petroleum-related socio-economic impact. Examples mentioned were educational and cultural initiatives, sporting events, youth competitions, church restoration, library construction, and support for war veterans and people with disabilities. Innovative projects included provision of satellite phones to reindeer herders on the tundra and a zero-interest credit programme for local enterprises, although the latter was discontinued when the head of the district moved elsewhere. Some residents felt that the petroleum companies were merely using their CSR endeavours to generate positive publicity for themselves, especially after an oil spill. 


\section{Kelman et al.}

A few interviewees recalled companies failing to keep their promises. One villager remembered a public hearing led by an oil company, where the villagers approved the oil company's proposed plan of work, but then 'They promised a lot and didn't deliver it. We won't believe them next time'.

The expectations of the Hammerfest interviewees were similar to their Russian counterparts, with comments weighed towards the positive side. In fact, practically all Hammerfest interviewees mentioned positive effects, particularly job opportunities countering depopulation; for example, 'Petroleum is extremely important for the whole region. It creates jobs, and that is the most important-if not, it would have been quite empty here'. The companies, to a certain degree, use local suppliers, which supports local businesses and gives economic power to the owners. Cultural and social events funded by the petroleum companies were seen by many as increasing the attractiveness of living in the community. Both Statoil and ENI support cultural and educational projects, with several interviewees mentioning town festivals where Statoil brought in famous Norwegian artists to give free concerts. The jobs offered are accepted as being highly skilled with commensurate salaries and benefits; therefore, there is no intimation of workers being exploited or of locals being undervalued.

The Hammerfest interviewees further noted the high visibility of the petroleum companies' contributions to the region, seen through the spending of the wealth generated. New buildings and refurbished façades are common, including kindergartens and other schools. Hammerfest sports a modern cultural centre with excellent acoustics, with some events supported by petroleum companies. Heated pavements in the centre of Hammerfest melt snow and ice, making it easy to walk and shop there. All of this signals new wealth in a town which previously was economically depressed. Because many of these infrastructure initiatives were paid for by the municipality using property taxes from the petroleum companies, interviewees tended to see these as effects of the petroleum industry melding with their CSR expectations as part of their general expectations of petroleum companies' contributions to the region.

\subsection{Responding to CSR's detrimental impacts}

Corruption and lack of access to CSR-related decision-making were concerns expressed in Komi. Decision-making power was centralised in Usinsk in 2009, making it more difficult for villagers to negotiate directly with petroleum companies. Consequently, many interviewees in the villages felt excluded from decision-making, while those in Usinsk did not indicate a similar dissatisfaction. Corruption was alluded to by interviewees particularly in relation to replacing corroded pipelines. Further complaints related to a lack of transparency and accountability regarding social investment funds.

Similar allegations of (mis)spending of funding for purposes other than reported were expressed in NAO, although these allegations were not documented; therefore, verification and assessment of the scope of the problem cannot be made on the basis of the interviews. In Hammerfest, no such allegations were made. Instead, people 
reported a high degree of trust in the local as well as national authorities for expenditures, distributing wealth, and carrying out activities honestly.

The case studies reveal a varying degree of potential for conflict over petroleum development and CSR activities. In Murmansk, much frustration was expressed regarding what the petroleum companies offered or were expected to offer but did not provide. Significant hope emerged when it appeared that the companies were going to exploit offshore reserves with the resultant expectation of CSR providing jobs and economic boons. After the companies were forced by market conditions to put the large-scale petroleum development of the Shtokman field on hold, the interviewees' mood was more along the lines of resignation over unfulfilled promises than bitterness or militancy towards the companies.

In three of the case studies-Hammerfest, Murmansk, and NAO - the environment was not highlighted as a main issue for CSR-related discussions. Interviewees in Komi, however, emphasised the environment as a core element of petroleum companies' responsibilities, and this issue was the greatest source of conflict. Expectations are that CSR, which by definition is the responsibility of companies, does not mean damaging local livelihoods and cleaning up historic and ongoing spills. In Komi, rural residents referred to the poor clean-up of the 1994 oil spill and the lasting damage to local fisheries. One resident from the village of Kolva said, 'We used to fish a lot in Kolva, [but] since 1994 the commercial fisheries have been destroyed'. The 2013 spill also damaged local livelihoods, but the perceived attempts to avoid informing villagers about it were of more concern. People have lost reindeer pastures, berry and mushroom picking sites, and hunting grounds to oil works, while reindeer are killed in collisions with vehicles along roads built for the petroleum industry. In the minds of local residents, CSR should mean replacing ageing and leaking pipelines faster and more effectively, reporting spills, providing fair compensation for environmental damage, and generally operating cleanly. Rural Komi interviewees believe that it is possible for the oil industry to operate cleanly so that they are not against the industry per se. A local entrepreneur said: 'We don't say "don't drill", but do it properly. Leave the land as you found it'.

Local groups in the Komi Republic have now started to protest against company operations in the region, in one case banning a company from operating in the area until it had met their demands for proper public consultation and pipeline replacement. These groups are assisted greatly by their links with international NGOs, notably Greenpeace, and extensive social media networks operating within the Komi Republic and internationally. For those without access to the Internet, local newspapers and environmental journals provide villagers with environmental information and links to civil society networks.

Several NAO interviewees, particularly from businesses and regional authorities, described a 'harmonious' region where different people - indigenous and nonindigenous as well as Russian and foreign - lived together and respected each other. In general, there appeared to be a positive attitude towards indigenous cultures and livelihoods. Many interviewees reported a relatively well-functioning and constructive interaction amongst oil and gas companies, regional authorities, and the 


\section{Kelman et al.}

population. Yet many challenges were raised by interviewees in less privileged positions. While mechanisms provide compensation for reindeer herders affected by petroleum activity, there was allegedly a need to improve how it works in practice. Some interviewees in NAO also pointed out the short-term perspectives of the agreements, which might benefit the herders immediately, but not future generations. While the regional authorities have systems in place for people to make complaints and to have their concerns addressed, some interviewees reported that they did not feel well-represented.

Another concern expressed by many NAO interviewees was that compensation for petroleum activities was only provided for people living in locations directly affected by petroleum production, rather than considering equity across the entire region, thereby also including people indirectly affected. Groups of people, who were previously on equal terms, now experienced differences in livelihoods due to differential compensation, which in some cases led to conflicts. For instance, according to interviewees, those living in locations directly affected by oil and gas activities gained compensation money and had access to more modern equipment compared to herders who were not directly affected. The conflict was not only related to wanting what others had but also related to the fact that choosing to live traditionally had become more difficult for the herders who wanted to preserve their traditional lifestyles and livelihoods rather than embrace petroleum and monetary compensation. In fact, highly divergent views were evident in NAO related to how oil companies should interact with the regional authorities and the local population. While some felt that the oil companies should deal with the population directly and control what CSR funding was spent for - covering compensation and social investment-others felt that it was more efficient for the authorities, who know the region better, to receive and redistribute money from companies.

In Hammerfest, a few of the interviewees expressed undercurrents of negative feelings about the petroleum activities, especially that some people were left out of the wealth and that affluence had changed values, creating a more money-focused and colder society. One interviewee explained, "We still have our friends and visit each other but it has kind of become a bit "colder". People care more about status, [material] things and expensive cars. People talk about buying new snow scooters and where they are planning to travel. The petroleum industry has created an illusion that having much money is happiness. It was different before. Calmer'. Many interviewees asserted that criticism of petroleum activities was unwelcome in Hammerfest so that few residents were willing to stand up in public to express their negative views.

Some indigenous Sami in and around Hammerfest expressed concerns over perceived restrictions on the ability of their reindeer herds to migrate. While the Snow White and Goliath fields are offshore, not directly affecting pastures or migration routes, industrial development generates increased land-based activity and infrastructure, which the interviewees suggested interferes with reindeer migration patterns. 
Despite local youth groups having protested against Hammerfest's petroleum activities, anti-petroleum sentiments were described by interviewees as largely emanating from external forces, such as NGOs and academics outside the region, mainly based in Oslo. According to interviewees, the environmental movement holds little currency locally. These feelings reinforced the understanding that CSR for petroleum was not explicit, different, or unusual, but part of the typical state of affairs. Hammerfest is 'blessed' with Barents petroleum; therefore, it should be extracted and the benefits should be accrued to the Hammerfest area.

\subsection{Summary of the results}

Overall, opinions of CSR and Arctic petroleum varied substantially across and within the case studies and did not follow clear community dividing lines, such as NGOs differing from businesses and indigenous interviewees differing from non-indigenous interviewees. Similarly, where disagreement was expressed, no intimation was made that protests, violence, or overt conflict would erupt. Instead, a general trend appears to emerge from the interviews that the petroleum industry is desired for the benefits which accrue from it, although those who do not benefit or who are affected negatively were more critical.

\section{Analysis and discussion}

The main pattern emerging from the results is the diversity of viewpoints. This diversity is evident in each of the case studies and across sectors within each case study. Nonetheless, Hammerfest is the least diverse, at least superficially, especially in terms of desiring and accepting the petroleum industry. The patterns of diversity suggest three aspects which are explored in more detail in this section: trust and transparency (section 6.1), the meaning of 'community' (section 6.2), and insideroutsider perspectives (section 6.3).

\subsection{Trust and transparency}

A significant lesson from the results relates to wider issues of trust and transparency, which are common themes in Arctic petroleum development. ${ }^{80}$ For the case studies here, different layers of trust and transparency emerge regarding where the residents' information about the petroleum industry comes from and their views on that information's credibility. Norway and Russia contrast in their official stances on transparency, with Norway being a leading proponent of the Extractives Industry Transparency Initiative, ${ }^{81}$ while Russia has so far not joined.

In Hammerfest, although gas extraction is offshore, the processing plant is located onshore, just $4 \mathrm{~km}$ from the town centre; so people see it and drive past it every day. Even during the dark Arctic winters, it is still conspicuous because the lights and flares continue to burn. Several interviewees articulated a sense of ownership and pride about the development of oil and gas in their town, and on various occasions, local inhabitants were invited by Statoil to visit the Milk Island plant. The visibility of and access to the gas plant might imbue feelings of transparency, especially given the inherent trust which most interviewees have for the companies and government 


\section{Kelman et al.}

regarding development of the petroleum industry. ${ }^{82}$ An underlying assumption exists on the part of local residents that negative impacts will not result because the Norwegian authorities monitor and control social and environmental consequences of industrial development.

In contrast to the visibility of the petroleum industry in Hammerfest, $\mathrm{NAO}$ is a vast region with petroleum production distant from where most people live and with much of the media owned by authorities who closely interact with the petroleum companies. Information about small leaks, spills, and other on-site incidents may not always be available; therefore, the people of the region are not necessarily aware of the day-to-day and long-term consequences.

In Komi, rural communities directly experience negative consequences when oil contaminates reindeer pastures or flows down rivers used by villagers for fishing. These direct negative experiences shaped the views of many interviewees, who emphasised the lack of transparency on the part of government and industry regarding operations and incidents, alongside a repeated failure of companies to take responsibility for spills. As a result, the companies and authorities have lost the trust of those directly affected. A further challenge is the fact that a strong 'social licence' has been established by the oil industry in the urban centre Usinsk, while the villagers who are most affected rarely get the opportunity to influence decisions or debates. ${ }^{83}$ The mainstream media does not cover rural concerns, but social media and international networks provide a highly effective outlet.

Meanwhile, Murmansk went through expectations of petroleum-related gains without experiencing any environmental or social problems once petroleum production gets underway. In a sense, the interviewees were neutral regarding trust and transparency. The mood was more of resignation than of betrayal, plus hope that new economic growth prospects might yet develop in the area.

\subsection{Whither 'community'?}

Referring to communities, companies, and authorities assumes that these three groups are distinct and internally homogenous. This assumption needs to be explored further in light of the results showing that local perceptions of CSR for Arctic petroleum display significant divergences.

In Hammerfest, the economic effects of the petroleum industry affect everyone. Property taxes from the Milk Island plant provide the municipality with approximately NOK 155 million a year, and the increased value of residential and business properties further boosts the municipality's tax base. This tax income has allowed the municipality to secure big loans which have financed the refurbishment of the town and various social services. The general level of wealth is higher than it was before, but prices have also increased due to greater demand for housing and services. While the salaries in petroleum-related jobs are comparatively high, salaries for public sector employees are relatively low. Large socio-economic differences amongst people in Hammerfest have emerged, in what was once a highly homogenous community in terms of low socio-economic levels. 
In NAO, the petroleum industry has also led to increased wealth locally, at least where the regional authorities provide social and cultural services and redistribute money from the oil companies, either from taxes or from direct agreements. ${ }^{84}$ In addition, oil companies interact with both regional authorities and reindeer herders affected by their activities, paying negotiated compensation. Few people from NAO have jobs in the petroleum industry, the reason of which, according to interviewees, is they do not have the right competencies. Instead, workers from other parts of the country or abroad are imported to work in the petroleum fields, few of whom pass through the regional capital. While several interviewees reported that job opportunities would be of high interest, few expressed expectations that they would personally reap petroleum-related jobs. Nonetheless, oil companies carrying out CSR measures were encouraged by representatives of the local population to support local employment, either through competence building and direct employment or through assisting small business development.

In the Komi Republic, many people in Usinsk, the district centre, have jobs relating directly to the oil industry or to related sectors, such as the construction and service industries. Even in the villages, some people are able to find work with the oil projects. They appreciate the employment opportunities, despite the fact that this does not create a vibrant local economy. Their main concern is the environmental impact on other local livelihood activities. The centralisation of decision-making has disempowered the villagers, especially in terms of environmental regulation and benefit-related negotiation. ${ }^{85}$ Despite internal community disagreement over how to respond to oil industry challenges, major incidents such as spills can mobilise people and lead to organised protests, as has happened several times in recent years.

Understanding the full dynamics of a location requires breaking down categories of governments, companies, and other community members to find the layers of roles present and differing views within each of these categories. The three Russian case studies provided a diversity of perspectives. In Hammerfest, homogeneity was at first apparent, but undercurrents of negativity were reported, displaying marked diversity as interviews became more in-depth. While practically all interviewees mentioned the positive effects of the petroleum activity, many also expressed concerns that other industries, with tourism being a prominent example, receive less support and are not prioritised locally. Consequently, caution is needed when discussing 'community' or 'community views' because, as other researchers have suggested in a participatory development context, ${ }^{86}$ groups are rarely homogenous and the concepts of 'community' - whether referring to a settlement, to a corporate entity, or to authorities - might not apply in reality. Rather than seeking unanimity amongst whichever 'community' is delineated, the manner of presenting views here in order to note similarities and differences might best depict perceptions from, rather than of, a community.

\subsection{Insider-outsider divisions}

The results indicate that those who reap rewards from petroleum development tend to be more positive towards petroleum than those who experience negative 


\section{Kelman et al.}

consequences directly, who tend to be more critical. Even this division is not straightforward because some people cross over into both categories of reaping rewards and experiencing negative consequences; therefore, nuances emerge regarding positive and critical views. A continuum can be postulated, with one end being inside or close to both the petroleum industry and the accompanying CSR benefits (labelled as 'insiders') and the other end being outside or far from both the petroleum industry and the accompanying CSR benefits (labelled as 'outsiders').

An important aspect of the insider-outsider picture relates to information access. In Usinsk District, locals perceive that the central administration and oil companies' information monopoly deliberately exclude them from the 'truth' about industry happenings. This situation is compounded by the perception that the regular media tend not to cover many of the villagers' key concerns and that the villagers do not receive timely warnings about planned oil industry activities or alerts about spills or incidents. A further angle on Komi's insider-outsider continuum relates to benefits distribution. In general, interviewees in Usinsk District recognised that they live in an oil region and appreciated the benefits from the petroleum industry. Usinsk benefits more directly than the villages, through employment and business opportunities; however, the villagers appreciate the benefits that they too receive, including employment and 'social partnership' projects. In a sense, while the villagers are, to a degree, insiders in the oil economy, they also feel like outsiders because the industry has failed to nurture economic growth and well-being in the villages. Moreover, the increased centralisation of power over recent years makes the villagers feel more and more sidelined from influence over the industry.

In NAO, the insider and outsider labels, respectively, reflect the people who benefit directly from petroleum activities and those who do not. The insider-outsider continuum was particularly poignant in NAO because many interviewees were part of several standard community sectors, such as working for both an indigenous NGO and for an oil company or the authorities. While interviewees working for the authorities, companies, or NGOs often talked about the positive sides of petroleum, unemployed people and people living in the tundra in some cases discussed abuses of power and limited transparency regarding the use of petroleum wealth to which they did not have access. Several interviewees reported that they were dissatisfied with the building of a new and prestigious water recreation park in NAO's capital Naryan-Mar, when people still need basic interventions such as clean drinking water and better sanitation systems. As one indigenous interviewee working in the local administration explained, 'People here need basic things, not luxuries. This is what CSR should provide'. Three interviewees expressed that the region could easily have been like the United Arab Emirates if only the petroleum-related money were distributed better. More privileged interviewees, however, warned against believing what 'less educated' people said, as the less-educated people allegedly did not understand fully how the system works.

In Hammerfest, social services and infrastructure development are provided mainly through the public sector. The role of businesses in these endeavours appears to be more limited than in the Russian cases. However, the insider-outsider 
continuum is still relevant for Hammerfest in terms of income disparities between relatively affluent households employed in the oil industry and relatively poorer households employed in the public sector or who are unemployed or living on social benefits. Simultaneously, all tax-funded facilities, events, and services are available to everyone, as with everywhere in Norway; therefore, the petroleum revenues in Hammerfest mean that everyone has some modicum of insider status.

This general pattern, but blurred divisions, of the divergent views of insiders and outsiders matches some of the economic theories in the literature. Insider-outsider analysis has been applied outside the CSR literature to describe privileged access to knowledge. ${ }^{87}$ This notion relates to recent discussions on how local perspectives are included in public debates on proposed oil and gas development in northern Norway. ${ }^{88}$ It is also relevant to the case studies in Russia and Norway presented here, in particular, the Komi case, where rural residents feel particularly isolated from influence over decisions. For Russia, the use of personal networks and 'insider' influences has been analysed in relation to day-to-day practices and surviving economic transition, ${ }^{89}$ plus more recently, for interpreting how economic and business relations have evolved in the post-socialist era. ${ }^{90}$

Being an insider or outsider - or being placed along the insider-outsider continuumcan also equate to levels of privilege gained within an economy. ${ }^{91}$ The results found in the four case studies here match this insider-outsider model in that those who gain benefits from petroleum, in effect privileges, are insiders and more positive about CSR-related activities. Similarly, secure employment within an industry is labelled as being an insider. ${ }^{92}$ Yet despite some employment, Komi villagers felt that they were economic outsiders because their villages were not thriving more generally due to the oil industry.

\section{Conclusions}

This paper offers one of the first comparative studies of local perceptions of CSR for Arctic petroleum across the Barents region and contributes to providing local, especially non-business, perspectives on petroleum development in the Arctic. The study's comparative nature has helped to generate insights into the importance of context for understanding companies' CSR practices and their local effects. While the comparison yields insights into differences and commonalities between Norway and Russia, it also reveals the diversity of contexts within one country, Russia, due to its size and, more importantly, its federal governance structure.

Unlike much CSR literature, this study has not focused on company policies or the views of corporate players; instead, it has explored the perspectives of people living within the local communities most affected by the corporate activities. As such, it sits well within a body of existing Arctic studies focusing on the relations between companies and communities, including CSR. The field data presented here reveal that the studied communities are not homogenous. The insider-outsider lens has rarely been used in CSR theory to date; however, it has been useful in this study in helping to explain the different perceptions of CSR in the studied locations. 


\section{Kelman et al.}

The divergence within certain communities along the insider-outsider continuum might not just be due to a direct experience of the positive or negative impacts of the petroleum industry. It might also relate to differential access to information and to different levels of trust in that information alongside preconceived opinions based on prior experience and historical legacies. While much company-orientated CSR literature seeks to identify patterns and trends, this study has revealed the importance of understanding complex groups interacting within specific contexts, showing that key tools for successful CSR practice include open-mindedness and willingness to engage in open dialogue on the terms of the people directly and indirectly affected.

\section{NOTES}

1. Herman Aguinis and Ante Glavas, 'What We Know and Don't Know about Corporate Social Responsibility: A Review and Research Agenda', fournal of Management 38 (2012): 932-68; Stephen Brammer, Gregory Jackson, and Dirk Matten, 'Corporate Social Responsibility and Institutional Theory: New Perspectives on Private Governance', Socioeconomic Review 10 (2012): 3-28; and Glenn Feldman, 'Putting Uncle Milton to Bed: Reexamining Milton Friedman's Essay on the Social Responsibility of Business', Labor Studies fournal 32 (2007): 125-41.

2. Jędrzej George Frynas, 'Corporate Social Responsibility in the Oil and Gas Sector', fournal of World Energy Law \& Business 2 (2009): 178-95; Evgeny Shvarts, Julia Bunina, and Alexey Kniznikov, 'Voluntary Environmental Standards in Key Russian Industries: A Comparative Analysis', International fournal of Sustainable Development and Planning 10 (2015): 331-46; Gerdien de Vries et al., 'Sustainability or Profitability. How Communicated Motives for Environmental Policy Affect Public Perceptions of Corporate Greenwashing', Corporate Social Responsibility and Environmental Management 22 (2015): 142-54; and Julia S.P. Loe and Ilan Kelman, 'Arctic Petroleum's Community Impacts: Local Perceptions from Hammerfest, Norway', Energy Research and Social Science 16 (2016): 24-34.

3. Kenneth De Roeck and Nathalie Delobbe, 'Do Environmental CSR Initiatives Serve Organizations' Legitimacy in the Oil Industry? Exploring Employees' Reactions through Organizational Identification Theory', fournal of Business Ethics 110 (2012): 397-412; and Emma Wilson and Judy Kuszewski, Shared Value, Shared Responsibility: A New Approach to Managing Contracting Chains in the Oil and Gas Industry (London: IIED, 2011).

4. Leo Paul Dana, Robert Brent Anderson and Aldene Meis-Mason, 'A Study of the Impact of Oil and Gas Development on the Dene First Nations of the Sahtu (Great Bear Lake) Region of the Canadian Northwest Territories (NWT)', fournal of Enterprising Communities: People and Places in the Global Economy 3 (2009): 94-117; Aslaug Mikkelsen and Oluf Langhelle, eds., Arctic Oil and Gas: Sustainability at Risk? (Routledge: Abingdon, 2008); and Emma Wilson and Florian Stammler, eds., 'The Oil and Gas Industry, Communities and the State', Special Issue of Sibirica 5 (2006): 1-160.

5. Anatoli Bourmistrov et al., eds., International Arctic Petroleum Cooperation: Barents Sea Scenarios (Routledge: Abingdon, 2015); Gunnar Thesen and Einar Leknes, 'Nord-Norge i norsk petroleumspolitikk- narrative og politisk endring', in Oljevirksomhetens inntog $i$ nord, eds. Peter Arbo and Bjørn Hersong (Oslo: Gyldendal Akademiske, 2010), 45-76; Atle Midttun, ed., CSR \& Beyond: A Nordic Perspective (Oslo: J W Cappelens Forlag, 2013); Arild Moe, 'Russian and Norwegian Petroleum Strategies in the Barents Sea', Arctic Review on Law and Politics 1 (2010): 225-48; and Emma Wilson, 'What Is the Social Licence to Operate? Local Perceptions of Oil and Gas Projects in Russia's Komi Republic and Sakhalin Island', The Extractive Industries and Society 3 (2016): 73-81. 
6. Treaty between the Kingdom of Norway and the Russian Federation concerning Maritime Delimitation and Cooperation in the Barents Sea and the Arctic Ocean, signed September $15,2010$.

7. James Henderson and Julia S.P. Loe, 'The Prospects and Challenges for Arctic Oil Development', Oil, Gas \& Energy Law 2 (2016), http://www.ogel.org/article.asp? key=3620 (accessed September 14, 2016).

8. Emma Wilson and Florian Stammler, 'Beyond Extractivism and Alternative Cosmologies: Arctic Communities and Extractive Industries in Uncertain Times', Introduction to Special Section of Extractive Industries and Society 3 (2016): 1-8.

9. Timo Pauli Karjalainen and Joachim Otto Habeck, "When "the Environment" Comes to Visit: Local Environmental Knowledge in the Far North of Russia', Environmental Values 13 (2004): 167-86; Florian Stammler, 'Oil Without Conflict? The Anthropology of Industrialisation in Northern Russia', in Crude Domination, eds. Andrea Behrends, Stephen P. Reyna and Günther Schlee (Oxford: Berghahn Books, 2011), pp. 243-69; Tuula Tuisku, 'Transition Period in the Nenets Autonomou Okrug: Changing and Unchanging Life of Nenets People', in People and the Land: Pathways to Reform in Post-Soviet Siberia, ed. Erich Kasten (Berlin: Dietrich Reimer Verlag, 2002), 189-205; E.P. Martynova I. and Natalia I. Novikova, Taz Nentsy in the Context of Oil and Gas Development: Ethnological (Anthropological) Expert Review (Moscow: A.G. Yakovlev Publishing House, 2011); and Anna Degteva and Christian Nellemann, 'Nenets Migration in the Landscape: Impacts of Industrial Development in Yamal Peninsula, Russia', Pastoralism: Research, Policy and Practice 3 (2013): 15.

10. Wilson, 'What Is the Social Licence to Operate?'; Natalia I. Novikova, Okhotniki $i$ neftyaniki: Issledovanie po yuridicheskoi antropologii [Hunters and Oil Workers: Research in Legal Anthropology] (Moscow: Nauka, 2014); Natalia I. Novikova and Emma Wilson, 'Korporativnaya sotsial'naya otvetstvennost': transformatsiya ponyatiya na zapade i znachimost' dlya korennykh narodov Rossii' [Corporate Social Responsibility: Evolution of the Concept in the West and the Implications for Indigenous Peoples of Russia], Ural'skii istoricheskii vestnik 2 (2015): 108-17; and Л.А. Рябова, В.В. Дидык, Е.А. Корчак, Е.П. Башмакова, Е.Е. Емельянова, 'Арктические моногорода Российской Федерации: социальные проблемы, пути их решения и роль ресурсных корпорпций//Корпоративное управление и инновационное развитие', Севра: Вестник Научно-исследовательского центра корпоративного права, управлепния и венчурного инвестирования Сыктывкарского госдарствнного униврситета 3 (2013): 34-50.

11. Allen L. White, Culture Matters: The Soul of CSR in Emerging Economies (Paris: Business for Social Responsibility, 2008); Jo Crotty, 'Corporate Social Responsibility in the Russian Federation: A Contextualised Approach', Business and Society forthcoming; and Ciaran O'Faircheallaigh and Saleem Ali, eds., Indigenous Peoples, the Extractive Industries and Corporate Social Responsibility (Sheffield: Greenleaf Publishing, 2008).

12. Eleanor Shaw, 'Marketing in the social enterprise context: is it entrepreneurial?', Qualitative Market Research: An International fournal 7 (2004): 194-205.

13. Howard Bowen, Social Responsibilities of the Businessman (New York: Harper and Row, 1953).

14. Archie B. Carroll, 'Corporate Social Responsibility: Evolution of a Definitional Construct', Business and Society 38 (1999): 268-95; Antonis Skouloudis, Konstantinos Evangelinos and Chrisovaladis Malesios, 'Priorities and Perceptions for Corporate Social Responsibility: An NGO Perspective', Corporate Social Responsibility and Environmental Management 22 (2015): 95-112; and Caroline D. Ditlev-Simonsen, Atle Middtun, 'What Motivates Managers to Pursue Corporate Responsibility? A Survey among Key Stakeholders', Corporate Social Responsibility and Environmental Management 18 (2011): 25-38.

15. Aguinis and Glavas, 'What We Know and Don't Know'; Brammer et al., 'Corporate Social Responsibility and Institutional Theory'; Alexander Dahlsrud, 'How Corporate Social 


\section{Kelman et al.}

Responsibility is Defined: An Analysis of 37 Definitions', Corporate Social Responsibility and Environmental Management 15 (2008): 1-13; and Louise Ellis and Claire Bastin, 'Corporate Social Responsibility in Times of Recession: Changing Discourses and Implications for Policy and Practice', Corporate Social Responsibility and Environmental Management 18 (2008): 294-305.

16. Mick Blowfield and Alan Murray, Corporate responsibility, 2nd ed. (New York: Oxford University Press, 2011).

17. Frank G.A. de Bakker, Peter Groenewegen, and Frank Den Hond, 'A Bibliometric Analysis of 30 Years of Research and Theory on Corporate Social Responsibility and Corporate Social Performance', Business E Society 44 (2005): 283-317.

18. Elisabet Garriga and Domènec Melé, 'Corporate Social Responsibility Theories: Mapping the Territory', fournal of Business Ethics 53 (2004): 51-71.

19. Alexander Dahlsrud, 'How Corporate Social Responsibility is Defined: An Analysis of 37 Definitions', Corporate Social Responsibility and Environmental Management 15 (2006): 1-13.

20. Archie B. Carroll, 'Corporate Social Responsibility: Evolution of a Definitional Construct', Business \& Society 38 (1999): 268-95.

21. Dana et al., 'A Study of the Impact of Oil and Gas Development'; Julia S.P. Loe et al., 'Arctic Petroleum: Local CSR Perceptions in the Nenets Region of Russia', Social Responsibility, forthcoming; and Emma Wilson, 'Negotiating Uncertainty: Corporate Responsibility and Greenland's Energy Future', Energy Research \& Social Science 16 (2016): 69-77.

22. Dirk Matten and Jeremy Moon, 'Implicit' and 'Explicit' CSR: A Conceptual Framework for Understanding CSR in Europe, No. 29-2004 ICCSR Research Paper Series (Nottingham, UK: International Centre for Corporate Social Responsibility, Nottingham University Business School, Nottingham University, 2004).

23. Abagail McWilliams and Donald Siegel, 'Social Responsibility and Financial Performance: Correlation or Misspecification?' Strategic Management fournal 21 (2000): 603-9.

24. Abagail McWilliams and Donald Siegel, 'Corporate Social Responsibility: A Theory of the Firm Perspective', The Academy of Management Review 26 (2001): 117-27.

25. François Maon, Adam Lindgreen and Valérie Swaen, 'Designing and Implementing Corporate Social Responsibility: An Integrative Framework Grounded in Theory and Practice', Fournal of Business Ethics 87 (2009): 71-89; and Wilson, 'What Is the Social Licence to Operate?'.

26. Uwem E. Ite, 'Multinationals and Corporate Social Responsibility in Developing Countries: A Case Study of Nigeria', Corporate Social Responsibility and Environmental Management 11 (2004): 1-11.

27. Rob Gray et al., 'Social and Environmental Disclosure and Corporate Characteristics: A Research Note and Extension', Journal of Business Finance and Accounting 28 (2001): 327-56.

28. Wilson, 'What is the Social Licence to Operate?'.

29. Loe and Kelman, 'Arctic Petroleum's Community Impacts'.

30. Graeme Auld, Steven Bernstein, and Benjamin Cashore, 'The New Corporate Social Responsibility', Annual Review of Environment and Resources 33 (2008): 413-35; Michael Barkusky and Frank Lorne, 'The Economic Logic of Corporate Social Responsibility: Implications for Strategy, Policy and Education', International fournal of Environment, Workplace and Employment 2 (2006): 148-79; and Nigel F. Piercy and Nikala Lane, 'Corporate Social Responsibility Initiatives and Strategic Marketing Imperatives', Social Business 1 (2011): 325-45.

31. Aaron Chatterii and Siona Listokin, 'Corporate Social Irresponsibility', Democracy: $A$ fournal of Ideas 3 (2007): 52-63. 
32. Wilson and Stammler, 'Beyond extractivism and alternative cosmologies'; Novikova, Okhotniki $i$ neftyaniki; and Gail Fondahl and Anna Sirina 'Rights and Risks: Evenki Concerns Regarding the Proposed Eastern Siberia-Pacific Ocean pipeline', Sibirica 5 (2006): 115-38.

33. OECD, OECD Guidelines for Multinational Enterprises 2011 Edition (Paris: OECD, 2011).

34. UN, UN Global Compact (New York: UN, 2016), https://www.unglobalcompact.org (accessed January 4, 2016).

35. UN, Guiding Principles on Business and Human Rights (New York: UN, 2011).

36. IFC, IFC Performance Standards on Environmental and Social Sustainability Effective fanuary 1, 2012 (Washington, DC: International Finance Corporation, World Bank Group, 2012).

37. OECD, Due Diligence Guidance for Meaningful Stakeholder Engagement in the Extractives Sector (Paris: OECD Publishing, 2016); and Emma Wilson et al., Meaningful Community Engagement in the Extractive Industries (London: IIED, 2016).

38. Wilson et al., Meaningful Community Engagement.

39. Laura Albareda et al., 'The Changing Role of Governments in Corporate Social Responsibility: Drivers and Responses', Business Ethics: A European Review 17 (2008): 347-63; and Halina Ward, Public sector roles in strengthening corporate social responsibility:taking stock (Washington DC: World Bank, 2004).

40. Abbi Buxton and Emma Wilson, FPIC and the Extractive Industries: A Guide to Implementing the Spirit of Free, Prior and Informed Consent in Industrial Projects (London: IIED, 2013); and Amy K. Lehr and Gare A. Smith, Implementing a Corporate Free, Prior, and Informed Consent Policy: Benefits and challenges (Boston, MA: Foley Hoag LLP, 2010).

41. Wilson, 'Negotiating uncertainty'.

42. Svetlana Tulaeva, 'Oil Companies, Reindeer-Herding Communities and Local Authorities: Rights to Land from the Perspective of Various Stakeholders', The International Indigenous Policy fournal, 5 (2014), http://ir.lib.uwo.ca/iipj/vol5/iss4/2 (accessed March 15, 2016).

43. Business and Human Rights Resource Centre, National Action Plans (Business and Human Rights Resource Centre, 2016), http://business-humanrights.org/en/un-guiding-principles/ implementation-tools-examples/implementation-by-governments/by-type-of-initiative/nationalaction-plans (accessed February 3, 2016).

44. Government of Norway Ministry of Foreign Affairs, Corporate Social Responsibility in a Global Economy, Report No. 10 (2008-2009) to the Storting (Oslo: Government of Norway, 2008-2009).

45. yvind Ihlen and Heidi von Weltzien Hoivik, 'Ye Olde CSR: The Historic Roots of Corporate Social Responsibility in Norway', fournal of Business Ethics 127 (2015): 109-20; and Midttun, CSR \& Beyond.

46. Maria Gjølberg, 'Varieties of Corporate Social Responsibility (CSR): CSR Meets the "Nordic Model”", Regulation E Governance 4 (2010): 203-29; and Atle Midttun et al., CSR, Innovation and Value Creation in Rapidly Growing Norwegian SMEs (Oslo: Centre for Corporate Responsibility, Norwegian Business School, 2013).

47. Daniel Buikema Fjærtoft, 'Modeling Russian Regional Economic Ripple Effects of the Oil and Gas Industry: Case Study of the Republic of Komi', Regional Research of Russia 5 (2015): 109-21.

48. Loe and Kelman, 'Arctic Petroleum's Community Impacts'.

49. Elena Bashmakova, 'Развитие корпоративной социальной ответственности на севеных и арктических территориях России', Север и рынок: Формирование экономического порядка 6 (2013): 71-80; Lev Tchourilov, Isabel Gorst, and Nina Poussenkova, Lifeblood of the Empire. Personal History of the Rise and Fall of the Soviet Oil Industry (Moscow: PIW Publications, 1996); and Susanne Wengle, Post-Soviet Power: State-Led Development and Russia's Marketization (New York: Cambridge University Press, 2015).

50. Novikova, Okhotniki i neftyaniki. 


\section{Kelman et al.}

51. Ibid.

52. Rusal, From Russia with Love: A National Chapter on the Global CSR Agenda (London: Rusal in Cooperation with The Economist Intelligence Unit, 2008); and Wilson and Stammler, 'Beyond Extractivism and Alternative Cosmologies'.

53. Novikova and Wilson, Korporativnaya sotsial'naya otvetstvennost'.

54. Liudmilla Alferova, 'Legal Provisions for Safeguarding the Rights of Indigenous Minorities of the North in the Khanty-Mansiisk Autonomous Region (Yugra), in Relation to Protection of their Ancestral Lands, Traditional Ways of Life and Livelihood Activities', Sibirica 5 (2006): 153-60.

55. Anna Degteva, 'Oil Industry and Reindeer Herding: The Problems of Implementing Indigenous Rights in the Nenets Autonomous Okrug, Russia' (master's thesis, Faculty of Social Science, University of Tromsø, Tromsø, 2006); Florian Stammler and Vladislav Peskov, 'Building a "Culture of Dialogue" among Stakeholders in North-West Russian Oil Extraction', Europe-Asia Studies 60 (2008): 831-49; and Tuula Tuisku, 'Nenets Reindeer Herding and Industrial Exploitation in Northwest Russia', Human Organization 61 (2002): 147-53.

56. Nina Poussenkova, 'Neftegazovoe osvoenie Arktiki: Chtoby v NAO bylo kak v OAE. (Oil and Gas Extraction in the Arctic: If Only It Could be Like the United Arab Emirates in the Nenets Autonomous Region)', Ekologicheskii vestnik Rossii 11 (2014), 25-31.

57. Kenneth De Roeck and Nathalie Delobbe, 'Do Environmental CSR Initiatives Serve Organizations' Legitimacy in the Oil Industry? Exploring Employees' Reactions through Organizational Identification Theory', Fournal of Business Ethics 110 (2012): 397-412; and Emma Wilson and Judy Kuszewski, Shared Value, Shared Responsibility: A New Approach to Managing Contracting Chains in the Oil and Gas Industry (London: IIED, 2011).

58. Rosalind Edwards and Janet Holland, What is Qualitative Interviewing? (London: Bloomsbury Academic, 2013); and Nigel King and Christine Horrocks, Interviews in Qualitative Research (Los Angeles, CA: Sage, 2010).

59. Earl R. Babbie, The Basics of Social Research, 4th ed. (Belmont, CA: Thomson Wadsworth, 2008); and Russell K. Schutt, Investigating the Social World: The Process and Practice of Research (Los Angeles, CA: Sage, 2012).

60. Edwards and Holland, What is Qualitative Interviewing?; and King and Horrocks, Interviews in Qualitative Research; and Babbie, The Basics of Social Research.

61. John W. Creswell, Research Design: Qualitative, Quantitative, and Mixed Methods Approaches, 2nd ed. (Thousand Oaks, CA: Sage, 2003); and Juliet Corbin and Anselm Strauss, Basics of Qualitative Research: Techniques and Procedures for Developing Grounded Theory, 2nd ed. (Thousand Oaks, CA: Sage, 1998).

62. Ukaz Prezidenta Rossijskoj Federacii ot 2 maja g. No [President of Russian Federation Decree] 02.05.2014 No. 296.

63. SSB, Folkemengde (Oslo: SSB, 2015), http://ssb.no/befolkning/statistikker/folkemengde (accessed November 23, 2015).

64. Ivar Lie and Stig Karlstad, Befolkningsutvikling og befolkningsframskriving Hammerfest. Analyser av demografi og framskrivingsalternativer for Hammerfest og nabokommunene (Tromsø: NORUT, 2014).

65. Sveinung Eikeland et al., Dette er Snøhvit, Norut Report 2009:3 (Alta: NORUT, 2009); and Caroline Sinclair, 'First Female Mayor Strikes Largest Oil Deal for Dying Hammerfest', in Culture, Development and Petroleum: An Ethnography of the High North, ed. Jan-Oddvar Sornes, Larry Browning, and Jan Terje (Abingdon: Routledge, 2015), 208-17.

66. NPD, ODs Faktasider - Snøhvit (Stavanger: NPD (Oljedirektoratet), 2015).

67. ENI, 'Work in ENI', http://www.eninorge.com/no/Jobb-i-Eni/Vare-kontorer/Hammerfest (accessed April 20, 2015).

68. Government of Russia, Russian Census of 2010 (Moscow: Government of Russia, 2010). 
69. Dag Harald Claes and Arild Moe, 'Arctic Petroleum Resources in a Regional and Global Perspective', in Geopolitics and Security in the Arctic, ed. Rolf Tamnes and Kristine Offerdal (London: Routledge, 2014), 97-120; and Vladimir Socor, 'Gazprom's Shtokman Project: Relic of a Past Era', Eurasia Daily Monitor 9 (2012): 153.

70. Claes and Moe, 'Arctic Petroleum Resources in a Regional and Global Perspective'.

71. Ibid.

72. Government of Russia, Russian census of 2010.

73. NAO, 'V $2013 \mathrm{v}$ okruge ozhidayut uvelichenie dobychi nefti. (Oil production in (the Nenets) okrug expected to increase in 2013)', Regional government press-release, http://adm-nao.ru/ press/government/559 (accessed March 20, 2015).

74. GKS, 'Struktura VRP po vidam ekonomicheckoi deyatelnosti. (GRP Structure by Economic Activity)', Datasheet, http://www.gks.ru/wps/wcm/connect/rosstat_main/rosstat/ru/statistics/ accounts/ (accessed March 20, 2015).

75. GKS, 'Valovoy regionalny product. (Gross Regional Product)', Datasheet, http://www.gks. $\mathrm{ru} / \mathrm{wps} / \mathrm{wcm} /$ connect/rosstat_main/rosstat/ru/statistics/accounts/ (accessed March 20, 2015).

76. Government of Russia, Russian census of 2010.

77. Oleg Khlevniuk and Rhiannon Dowling, 'No Total Totality: Forced Labor, Stalinism, and De-Stalinization', Kritika: Explorations in Russian and Eurasian History 16 (2015): 961-73; and Tomas Kazulenas, 'In the Footsteps of the Gulag', Lituanus 57 (2011): 32-48.

78. Arne Jernelov, 'The Threats from Oil Spills: Now, Then, and in the Future', AMBIO, 39 (2010): 353-66; and TED, 'TED Case Studies: Russia Oil Spill', Case number 265, Trade and Environment Database (Washington, DC: American University, 1997).

79. Lukoil, Sustainability Report 2005-2006 (Moscow: Lukoil, 2006).

80. Loe and Kelman, 'Arctic Petroleum's Community Impacts'; Loe et al., 'Arctic Petroleum'; Aslaug Mikkelsen and Oluf Langhelle, eds., Arctic Oil and Gas: Sustainability at Risk? (Abingdon: Routledge, 2008); Wilson, 'What is the Social Licence to Operate?'; and Emma Wilson, 'Rights and Responsibilities: Sustainability and Stakeholder Relations in the Russian Oil and Gas Sector', in Northern Sustainabilities, eds. Gail Fondahl and Gary Wilson (Vancouver: University of British Columbia Press, forthcoming).

81. Susan Ariel Aaronson, 'Limited Partnership: Business, Government, Civil Society, and the Public in the Extractive Industries Transparency Initiative (EITI)', Public Administration and Development 31 (2011): 50-63; and Benjamin K. Sovacool et al., 'Energy Governance, Transnational Rules, and the Resource Curse: Exploring the Effectiveness of the Extractive Industries Transparency Initiative (EITI)', World Development 83 (2016): 179-92.

82. Eero Olli, Gunnar Grendstad, and Dag Wollebaek, 'Correlates of Environmental Behaviors: Bringing Back Social Context', Environment and Behavior 33 (2001): 181-208; and Geir I. Orderud and Ilan Kelman, 'Norwegian Mayoral Awareness of and Attitudes towards Climate Change', International fournal of Environmental Studies 68 (2011): 667-86.

83. Wilson, 'What is the Social Licence to Operate?'.

84. Loe et al., 'Arctic Petroleum'.

85. Wilson, 'What is the Social Licence to Operate?'; and Emma Wilson and Daniel Buikema Fjærtoft, 'Partnership or Dependency? Local Perceptions of the Petroleum Industry Ripple Effect in the Komi Republic', Russian Analytical Digest 181 (2016): 12-15.

86. Terry Cannon, 'Reducing People's Vulnerability to Natural Hazards: Communities and Resilience' (paper presented at the WIDER Conference on Fragile States-Fragile Groups: Tackling Economic and Social Vulnerability, 15-16 June 2007, Helsinki: UNU-WIDER, 2007); and Jim Walmsley, 'The Nature of Community: Putting Community in Place', Dialogue 25 (2006): 5-12.

87. Robert K. Merton, 'Insiders and Outsiders: A Chapter in the Sociology of Knowledge', American fournal of Sociology 78 (1972): 9-27; Assar Lindbeck and Dennis Snower, 
The Insider-Outsider Theory: A Survey, Discussion Paper No.534, July 2002 (Bonn: Institute for the Study of Labour).

88. Brigt Dale, 'Governing Resources, Governing Mentalities. Petroleum and the Norwegian Integrated Ecosystem-Based Management Plan for the Barents and Lofoten Seas in 2011', The Extractive Industries and Society 3 (2016): 9-16.

89. Alena Ledeneva, Russia's Economy of Favours: Blat, Networking and Informal Exchange (Cambridge: Cambridge University Press, 1998).

90. Brittney A. Lenard, 'Outsiders in an Insider Game: The Effects of the Traditional Soviet Economy of Favors on Foreigners Doing Business in Contemporary Russia' (Pomona senior theses, Paper 67, Claremont, U.S.A: Pomona College, 2012); and Alena Ledeneva, 'Economies of Favours or Corrupt Societies: Exploring the Boundaries between Informality and Corruption', Baltic Worlds 1 (2014): 13-21.

91. Assar Lindbeck and Dennis J. Snower, 'Insiders versus Outsiders', fournal of Economic Perspectives 15 (2001): 165-88.

92. David Rueda, 'Insider-Outsider Politics in Industrialized Democracies: The Challenge to Social Democratic Parties', American Political Science 99 (2005): 61-74. 